\section{S0SIAfLL- Lä̈̈HETIETEELLINEW AIHAHAUSLEHTI}

Journal of Social Medicine

Päätoimittaja

Sari Räisänen

editor@socialmedicine.fi

Toimitussihteeri

Suvi Määttä

Puh. 0405937048

toimitussihteeri@ socialmedicine.fi

Toimitusneuvosto

Anssi Auvinen, Heikki Hiilamo, Ilmo Keskimäki, Leena Koivusilta, Simo Kokko, Seppo Koskinen, Pekka Louhiala, Esa Läärä, Sami Pirkola, Ossi Rahkonen, Arja Rimpelä, Eva Roos ja Päivi Topo

Julkaisija

Sosiaalilääketieteen yhdistys ry

Socialmedicinska föreningen of

Puheenjohtaja

Peija Haaramo

Terveyden ja hyvinvoinnin laitos

PL 30

0027 I Helsinki

Sihteeri

Sanni Helander

Suomen Syöpärekisteri

Unioninkatu 20-22

00120 Helsinki

sihteeri@socialmedicine.fi

Neljä numeroa vuodessa

Tilaushinnat vuonna 2018:

Jäsenet $45 €$, opiskelijat $20 €$

(Sosiaalilääketieteen yhdistyksen jäsenmaksu)

Muut, yhteisöt ja tilaukset ulkomaille 50€, irtonumerot $13 €+$ postituskulut

Tämä julkaisu on saanut TSV:n kautta tieteellisen julkaisutoiminnan avustusta, jota opetus- ja kulttuuriministeriö myöntää Veikkauksen tuotoista

ISSN 0355-5097

Kirjapaino Hermes 0y 2018

\title{
Sosiaalilääketieteen yhdistys 50 vuotta
}

\section{Köyhän ei kannata sairastaa?}

Pääministeri Sipilän hallitus lienee oppinut, etteivät politiikassa asiat mene kuten matematiikassa, vaan kysymyksessä on laajempi logiikka. Terveydenhuollon kustannusten pienentäminen on varmasti hyvä tavoite, kunhan sen vaikutukset eivät ole negatiiviset palvelujen laadun tai saatavuuden suhteen. Kaikkien kolmen tavoitteen: laadun, saatavuuden ja kustannusten pitäminen kohdallaan samanaikaisesti on lähes mahdotonta.

Tavoitteena on kuitenkin tasa-arvon nimissä kaikkien ihmisten hyvän takaaminen. Tällöin lääketieteen käytettävissä olevat keinot ovat riittämättömät. Ihmisten yhteiskunnallisen aseman huomioiminen on vielä useamman tekijän yhtälö. Ja kaikissa niissä näyttää olevan tuntemattomia muuttujia.

Sosiaalilääketiede on jo pitkään pyrkinyt ottamaan huomioon ihmisen kokonaishyvinvoinnin. Köyhyys on muutakin kuin rahan puutetta. Kuitenkin jo pelkästään ihmisen taloudellisen tilanteen huomioiminen on lukuisten muuttujien vuoksi vaikeasti tasapainotettava asia. Verotuksen ja palvelujen hinnoittelun synkronointi johtaa tuloloukkuihin. Yksinkertaisinta on yleensä palvelujen maksuttomuus yhdistettynä verotukseen. Silloinkin tietysti ongelmaksi jää ihmisten haluttomuus terveenä harkita omaa riskiään sairastua. Palveluja tarvittuaan joko itselle tai läheiselleen silmät kyllä avautuvat.

Pohjoismaat näyttävät kuitenkin onnistuneen melko hyvin ihmisten kasvattamisessa pitkäjänteisyyteen ja jossain määrin solidaarisuuteen jopa sukupolvien välilläkin. Tämä näyttää heijastuvan myös ihmisten suhtautumiseen kansain- 
väliseen yhteistyöhön ja kestävään kehitykseenkin. Haasteet ovat kuitenkin melkoiset.

YK:n vuosituhattavoitteet vuonna 2000 oli ensimmäinen yritys laaja-alaiseen globaaliin ihmisen kaikenpuolisen hyvinvoinnin takaamiseen. Kysymys oli vain poliittisesti - ei juridisesti - velvoittavasta sitoumuksesta. Mutta sillä osoittautui olevan suurempi merkitys kuin mitä pessimistit arvioivat. Maailman lapset saatiin yleisesti arvioituna aloittamaan koulunkäynnin eräitä syrjäisiä vähemmistöjä lukuun ottamatta. Tämä on tietysti hyvinvointikehityksen kannalta tärkeä asia.

YK:n kestävän kehityksen tavoitteet hyväksyttiin vuosituhattavoitteiden täytäntöönpanokauden päättyessä vuonna 2015. Kyseessä on paljon laajempi kokonaisuus ihmiskunnan tulevaisuuden suhteen. Ihmisen vaikutus ympäristöön ja päinvastoin on keskeinen teema. Tämä ei kuitenkaan merkitse sosiaalisen oikeudenmukaisuuden merkityksen pienenemistä. Itse asiassa hyvinvointiyhteiskunta on melkeinpä eräänlainen esivaihe kestävään kehitykseen.

Ihmisten halu toimia itsensä ja läheistensä hyväksi toimii hyvin sopusoinnussa koko yhteiskunnan eteen tehtävän työn kanssa. Ihmisellä on oltava realistinen käsitys siitä, että yhdessä toimimalla voidaan parantaa myös omaa hyvinvointia. Maailman luonnonvarojen käytön kasvu on lisännyt ja tulee lisäämään tämän yhteisen vastuun merkitystä. Mutta jos ihmiset eivät näe, että tämä ponnistelu on todella "meidän kaikkien” hyväksi, kärsii sekä yhteiskunnan oikeudenmukaisuus että tehokkuus.

Hyvinvointierot ovat selvästi vielä näkyvissä pohjoisen ja etelän välillä, mutta kuva on monitahoisempi. Yhteiskuntien sisällä on tapahtunut sekä myönteistä että kielteistä kehitystä. Myös tutkimustavoissa on muutoksia. Uusiin tutkimustapoihin kuuluu mm. sukupuolen huomioon ottaminen aineistossa. Naisten ja tyttöjen hyvinvointi on edelleen huonompi kuin miesten ja poikien globaalilla tasolla.

Suomessahan kuva on monimutkaisempi. Taloudellisesti naiset ovat edelleen miehiä heikommassa asemassa sekä ansiotyössä että eläkkeellä, mutta eräät muut hyvinvointitekijät kuten eliniänodote on naisilla korkeampi kuin miehillä. Tyttöjen ja naisten parempi koulutustaso tai positiivisemmat elintavat kertovat mielestäni nais- ten ja tyttöjen aktiivisuudesta oman elämänsä suhteen. Suomi on monessa suhteessa myönteinen esimerkki tyttöjen ja naisten aseman parantamisesta.

Globaalisti sukupuolten tasa-arvon kehittäminen on edelleen kiireisesti korjattava asia sekä ihmisten tasa-arvon että yhteiskunnan voimavarojen tuhlaamisen kannalta. Huoli naisten ja tyttöjen terveyden ja laajemminkin hyvinvoinnin suhteen vahvistui teemana jo edellisen YK:n pääsihteeri Ban Ki-moonin aikana. Silloin perustettiin Every Woman Every Child -työryhmä suoraan pääsihteerin alaisuuteen. Olen ollut yksi varapuheenjohtajista ja oma alueeni on ollut ihmisoikeudet. Olemme nostaneet uudeksi näkökulmaksi naisten ja tyttöjen oikeuden terveydenhuoltoon ihmisoikeusasiana. Etenkin kansalaisjärjestöt ovat korostaneet seksuaali- ja lisääntymisterveyden ja -oikeuksien olevan tärkeä osa naisten ja tyttöjen ihmisoikeuksia.

Olen täysin samaa mieltä. Tyttöjen, sittemmin naisten koulunkäynti lakkaa tai se pyritään lopettamaan juuri tyttöjen sukukypsyyden kynnyksellä suojeluun tai koulunkäynnin tarpeettomuuteen vedoten. Koulutuksen vähäisyys näkyy läpi elämän niin työelämässä kuin yhteiskunnallisessa toiminnassa muutoinkin.

WHO:n ja YK:n ihmisoikeuskomissaarin päätöksellä asiantuntijatyöryhmän tekemän raportin pohjalta tehtiin yhteistyösopimus, jolla pyritään näiden periaatteiden täytäntöönpanoon.

Onnistuminen on jäsenmaiden tahdon varassa. En usko, että pääsemme eteenpäin vielä pitkään aikaan yleisellä sopimuksella, vaan ehkä helpommin maakohtaisilla sitoumuksilla. Tällaisten edelläkävijämaiden tukeminen olisi erittäin tärkeää kehityksen nopeuttamiseksi.

Suomen kokemukset perheneuvonnasta, aborttilainsäädännöstä tai äitiysavustusten ja äitiysterveydenhuollosta yhdistämisestä ovat todella hyödyllisiä. Muiden kokemuksista oppiminen on tehokasta.

Sama pätee meidänkin osalta. Terveydenhuoltoa voidaan tehdä hyvinkin erilaisissa järjestelmissä. Liian suurisuuntaisten uudistusten vaarana on yhteisvaikutusten arvaamattomuus. Pelkästään markkinoiden varassa olevat terveyspalvelut ottavat huonosti huomioon sosiaalisen oikeudenmukaisuuden. Kysymys ei ole poliittisesta mielipiteestä, vaan tilastollisestikin todennetta- 
vasta faktasta. Nykyistä suuremman dynamiikan aikaansaaminen myös terveydenhuollon ja laajemminkin sosiaalisen hyvinvoinnin alueella on sinänsä tärkeä tavoite, mutta sen aikaansaaminen on hyvin monisäikeinen asia.

Toiminnan tavoitteena tulee olla ihmisoikeuksien kunnioittaminen. Tässä valtioilla on aivan erityinen roolinsa. Toivon sosiaalilääketieteen asiantuntijoille rohkeutta ja kärsivällisyyttä nähdä laajasti ihmisen hyvinvointi ja toteuttaa sitä käytännössä. Kiitos ansiokkaasta toiminnastanne!

Tarja Halonen 